\title{
Hypoxia induces p53-dependent transactivation and Fas/CD95-dependent apoptosis
}

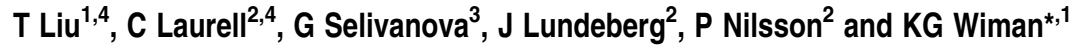

p53 triggers apoptosis in response to cellular stress. We analyzed p53-dependent gene and protein expression in response to hypoxia using wild-type p53-carrying or p53 null HCT116 colon carcinoma cells. Hypoxia induced p53 protein levels and p53dependent apoptosis in these cells. CDNA microarray analysis revealed that only a limited number of genes were regulated by p53 upon hypoxia. Most classical p53 target genes were not upregulated. However, we found that Fas/CD95 was significantly induced in response to hypoxia in a p53-dependent manner, along with several novel p53 target genes including ANXA1, DDIT3/ GADD153 (CHOP), SEL1L and SMURF1. Disruption of Fas/CD95 signalling using anti-Fas-blocking antibody or a caspase 8 inhibitor abrogated p53-induced apoptosis in response to hypoxia. We conclude that hypoxia triggers a p53-dependent gene expression pattern distinct from that induced by other stress agents and that Fas/CD95 is a critical regulator of p53-dependent apoptosis upon hypoxia.

Cell Death and Differentiation (2007) 14, 411-421. doi:10.1038/sj.cdd.4402022; published online 18 August 2006

The tumor suppressor p53 regulates cellular processes such as cell cycle progression, DNA repair and apoptosis. ${ }^{1}$ p53 is stabilized and activated in response to different types of cellular stress, for example, DNA damage, oncogenic signalling and hypoxia, and induces a biological response through transcriptional regulation of downstream target genes. The molecular mechanisms that dictate the decision of a cell to enter growth arrest or undergo apoptosis or both in response to p53 activation are only partially understood. Also, it remains unclear why different cell types display differential response to functional p53. The biological outcome of p53 activation presumably depends on several factors, including cellular context, cell type and type of stress agent. $^{1}$ It is plausible that p53 activates different specific and possibly overlapping set of target genes in response to different stress signals. Therefore, knowledge about the target genes and their regulation under different conditions is vital for the understanding of p53-mediated tumor suppression.

Previous DNA microarray studies have allowed a global analysis of p53-dependent gene expression in response to p53 activation by various means. ${ }^{2,3}$ These studies have indicated that several hundred genes are potentially regulated by $\mathrm{p} 53$. Moreover, in silico analysis of the human genome sequence has revealed that up to 4800 genes contain one or more potential p53 binding sites. ${ }^{4,5}$ Thus, it is conceivable that a large number of genes are regulated by p53, although not necessarily in the same cell in response to the same stress signal. Microarray studies have so far relied on artificial cell systems for activation of p53, for example, the metal- lothionein promoter or expression of exogenous p53. In addition, the numbers of genes on the arrays used have been relatively low. Thus, further studies of p53-dependent gene expression based on activation of endogenous p53 in response to physiological cellular stress should provide more reliable information about p53-dependent stress responses.

Hypoxia is a stress condition that probably has a great impact on tumor development in vivo. The hypoxic microenvironment in a solid tumor before the establishment of a sufficient blood supply may induce a p53 response and thus impose a selection for p53 point mutation. Hypoxia or anoxia has been shown to induce p53 accumulation and apoptosis. ${ }^{6,7}$ However, p53 activation by hypoxia does not appear to induce expression of classical p53 target genes such as p21, MDM2 and Bax, but can still mediate transrepression of certain genes such as $\alpha$-tubulin. ${ }^{8}$ This indicates that activation of p53 in response to hypoxia leads to a gene expression pattern that is different from that induced by p53 in response to $\gamma$-irradiation, ultraviolet (UV) light and other DNA-damaging agents.

Here, we present the first analysis of p53-dependent gene expression patterns in hypoxia-treated human cells using cDNA microarrays. We have found that hypoxia does not induce most classical p53 target genes but induces several genes that were previously not known to be regulated in a p53-dependent manner. Moreover, we found that the death receptor Fas/CD95 is upregulated by p53 in response to hypoxia and plays a major role in hypoxia-induced p53dependent apoptosis.

\footnotetext{
${ }^{1}$ Department of Oncology-Pathology, Cancer Center Karolinska (CCK), Karolinska Institute, Stockholm, Sweden; ${ }^{2}$ Department of Gene Technology, School of Biotechnology, KTH - Royal Institute of Technology, Stockholm, Sweden and ${ }^{3}$ Microbiology and Tumor Biology Center (MTC), Karolinska Institute, Stockholm, Sweden ${ }^{*}$ Corresponding author: KG Wiman, Department of Oncology-Pathology, Cancer Center Karolinska (CCK), Karolinska Institute, SE-171 76 Stockholm, Sweden. Tel: + 4685177 9342; Fax: + 4683210 47; E-mail: Klas.Wiman@ki.se ${ }^{4}$ These authors contributed equally to this work.

Keywords: p53; hypoxia; apoptosis; microarray analysis; p53 target genes

Abbreviations: EST, expressed sequence tag; FACS, fluorescence-activated cell sorter; FBS, fetal bovine serum; HDF, human diploid fibroblast; HIF1, hypoxia inducible factor-1; HRE, HIF1-responsive element; RT-PCR, reverse transcription-polymerase chain reaction; UV, ultraviolet light; wt, wild-type

Received 25.11.05; revised 10.7.06; accepted 11.7.06; Edited by M Oren; published online 18.8.06
} 


\section{Results}

p53-dependent apoptosis in hypoxia-treated HCT116 cells. To determine whether hypoxia induces p53 protein accumulation in HCT116 wtp53+/ + cells, we cultured the cells at $0.3 \% \mathrm{O}_{2}$ and examined p53 protein levels by Western blotting at 8 and $16 \mathrm{~h}$. p53 was significantly induced under hypoxic conditions and accumulated in the nucleus (Figure $1 \mathrm{a}, \mathrm{b}$ ). We obtained the same results with $0.05 \% \mathrm{O}_{2}$ (data not shown). A similar induction of p53 was observed after treatment with UV $\left(12.5,25\right.$ or $\left.50 \mathrm{~mJ} / \mathrm{cm}^{2}\right)$, or $\gamma$-irradiation (5, 10 or $20 \mathrm{~Gy}$ ) (data not shown). Western blot analysis demonstrated that hypoxia causes p53 Ser-15 phosphorylation (Figure 1c), in agreement with a previous report. ${ }^{9}$ To examine hypoxia-induced apoptosis in the presence or absence of wild-type (wt) p53, HCT116 cells were grown at $0.3 \% \mathrm{O}_{2}$ for $24 \mathrm{~h}$ and analyzed by TUNEL staining. We observed a significant increase in the fraction of TUNEL-positive cells in the HCT116 wtp53 + / + cultures upon hypoxia treatment, but not among the p53 null HCT116 cells (Figure 1d). Only a few TUNEL-positive cells were observed in both cell lines under normoxic growth conditions. Similar results were obtained with $0.05 \% \quad \mathrm{O}_{2}$ (data not shown). We confirmed hypoxia-induced p53-dependent apoptosis at 36 and $48 \mathrm{~h}$ by propidium iodide staining and flow cytometry (see below; Figure $5 \mathrm{c}$, d). Thus, hypoxia induces p53-dependent apoptosis in the HCT116 cells.

\section{Microarray analysis of p53-dependent gene expression} in response to hypoxia. We performed microarray analysis to study gene expression in HCT116 wtp53+/+ and HCT116 p53 null cells upon hypoxia treatment $\left(0.05 \% \mathrm{O}_{2}\right)$ for 8 and $16 \mathrm{~h}$ We observed altered transcription levels of several thousand genes in response to hypoxia in both HCT116 cell lines, whereas p53-dependent changes in expression were limited to a few hundred genes. With our criteria for significant differential expression (see Materials and Methods), the estimated total number of hypoxia-
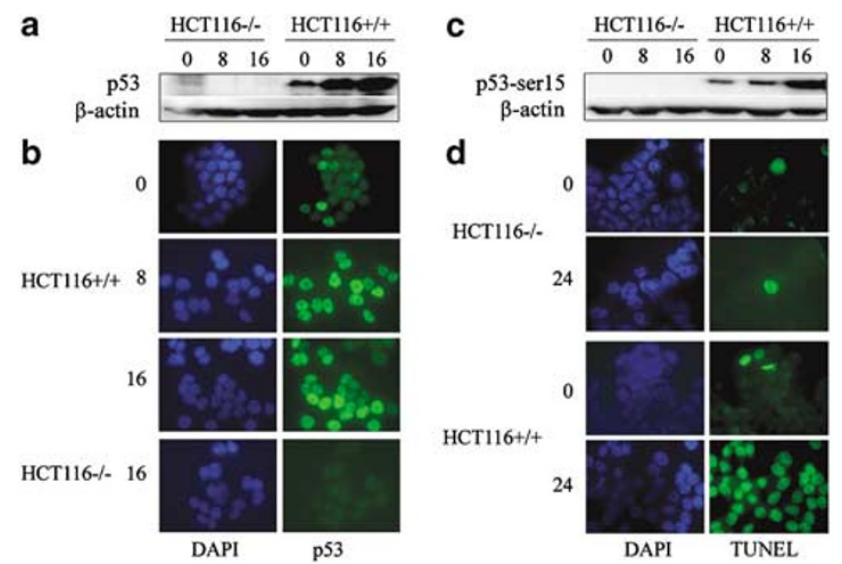

Figure 1 Induction of p53 protein and apoptosis in hypoxia-treated HCT116 cells. (a) Western blot analysis of p53 expression at different time points. $\beta$-Actin was used as loading control. (b) Immunofluorescence staining of p53. (c) Western blot analysis of p53 Ser-15 phosphorylation. (d) Visualization of apoptotic cells by TUNEL staining. Magnification was $\times 60$ in all panels dependent differentially expressed genes was 365 , of which 27 were p53-dependent (Table 1). This indicates that $8 \%$ of the transcripts undergoing hypoxia-induced changes in abundance are affected by wtp53. Among the 27 genes found to be regulated by hypoxia in a p53-dependent manner, 22 are known genes and five are expressed sequence tags (ESTs) of unknown origin (indicated as 'data not found' in Table 1). Sixteen genes were regulated at the $8 \mathrm{~h}$ time point, whereas another 11 genes only showed differential expression at $16 \mathrm{~h}$ of hypoxia. Prominin1 and Muscleblind-like 2 were upregulated at both 8 and $16 \mathrm{~h}$. The majority of the p53-dependent differentially expressed genes (24 out of 27) were upregulated in the hypoxia-treated cells. HIAP1 (apoptosis inhibitor 2)/BIRC3, and two unknown ESTs were repressed in a p53-dependent manner, and SLC2A3 showed significantly stronger induction in the p53 null cells at $8 \mathrm{~h}$ of hypoxia. Most of the identified p53-regulated genes carry one or several potential p53 DNA binding motifs. There was no apparent correlation between the score of the identified motifs according to the $\mathrm{p} 53 \mathrm{MH}$ algorithm ${ }^{4}$ and the degree of p53-dependent gene expression. For instance, angiomotin-like 2 (AMOTL2) which has a score of $<0.85$ was markedly induced at $8 \mathrm{~h}$ of hypoxia (Table 1). Moreover, the p53-repressed gene HIAP1/BIRC3 also contains potential p53 binding sites.

Only one of the identified p53-regulated genes, the death receptor TNFRS6 or Fas/CD95, is a previously known p53 target gene. According to the microarray analysis, Fas/CD95 was induced 2.4 -fold after $16 \mathrm{~h}$ of hypoxia treatment in the HCT116 wtp53 + / + cells. Fas/CD95 was not induced in the p53 null HCT116 cells at this time point, and was in fact slightly repressed at $8 \mathrm{~h}$.

The list of genes that shows p53-dependent expression upon hypoxia includes several genes that may be involved in regulation of cell growth, DNA-damage responses or apoptosis, for example, ANXA1 (apoptosis), DDIT3, also known as GADD153 or CHOP (DNA damage), SMURF1 and SMURF2 (regulators of the TGF- $\beta$ pathway) and HIAP1/BIRC3 (apoptosis) (see Discussion).

We specifically addressed the expression of the 283 genes on the array that are involved in apoptosis according to the Gene Ontology nomenclature (Figure 2). Twelve of these showed significant differential expression in response to hypoxia but only two, Fas/CD95 and HIAP1/BIRC3, were regulated in a p53-dependent manner. Fas/CD95 was significantly induced (see above) and HIAP1/BIRC3 was significantly repressed at $8 \mathrm{~h}$.

General hypoxia-induced changes in transcription levels. The vast majority ( $87 \%$ ) of the 365 genes that were affected by hypoxia treatment were upregulated. The main molecular mediator of the hypoxic response is the transcription factor hypoxia inducible factor-1 (HIF1). HIF1 target genes are mainly involved in processes related to adaptation to the hypoxic environment such as angiogenesis, glycolysis and erythropoiesis. We did not detect any upregulation of HIF1 at the transcriptional level, in agreement with earlier studies. ${ }^{10}$ A large number of genes with significantly altered mRNA levels in our study are already known to be hypoxia-regulated with characterized 


\begin{tabular}{|c|c|c|c|c|c|c|c|c|c|c|}
\hline \multirow[b]{3}{*}{ Name } & \multirow[b]{3}{*}{ Symbol } & \multirow[b]{3}{*}{ UGCluster } & \multirow[b]{3}{*}{ Accession } & \multicolumn{4}{|c|}{ Expression (fold change) } & \multirow[b]{3}{*}{$\begin{array}{l}\text { Score p53 MH } \\
\text { algorithm }^{\mathrm{a}}\end{array}$} & \multirow[b]{3}{*}{$\begin{array}{c}\text { Putative } \\
\text { binding site }\end{array}$} & \multirow[b]{3}{*}{$\begin{array}{l}\text { Putative } p 53 \text { binding } \\
\text { sequence }\end{array}$} \\
\hline & & & & \multicolumn{2}{|c|}{ p53+/+ } & \multicolumn{2}{|c|}{ p53-I- } & & & \\
\hline & & & & $8 \mathrm{~h}$ & $16 \mathrm{~h}$ & $8 \mathrm{~h}$ & $16 \mathrm{~h}$ & & & \\
\hline \multicolumn{11}{|l|}{ After $8 h$} \\
\hline $\begin{array}{l}\text { Additional sex combs like } 1 \\
\text { (Drosophila) }\end{array}$ & ASXL1 & Hs.3686 & AA485878 & 2.4 & 1.7 & 1.2 & 1.2 & 88.89 & -9828 & \multirow{16}{*}{$\begin{array}{l}\text { TAACTAGCTG TGTTACCTT } \\
\text { GAACAAGTTA } \\
\text { AGCCCAGCCC } \\
\text { ACAGCATGGA } \\
\text { AAGCAAGCCC } \\
\text { GGTCTAGTTC } \\
\text { CTTGTTTTGTGTT } \\
\text { CAACTAGTCT } \\
\text { GAACTTGATG CTCAGAGA } \\
\text { GGACAAGTCA } \\
\text { TACCAAGTTT } \\
\text { GCTTTTAATTTGA } \\
\text { AAACTTGTCA } \\
\text { AACCAAGCC } \\
\text { CTATCTTGG AAACTTGTTT } \\
\text { AGTCTTGCTA CGTTGCCC } \\
\text { AGGCTAGTCT } \\
\text { TCACATGACC } \\
\text { ACAGCTTAAGGGCT } \\
\text { GGGCATGTCC } \\
\text { CAGCTTGTGC GACA } \\
\text { AAGCAAGACT } \\
\text { CAGCTTGTGC GACA } \\
\text { AAGCAAGACT } \\
\text { TATCTAGCTC } \\
\text { ACAAAGTGACAG } \\
\text { CAGCTTGCTC } \\
\text { GAGCATGTTG } \\
\text { GCACAAGCCT } \\
\text { AGGCATGACT A } \\
\text { TAGCAAGTAC } \\
\text { AAACAAGTTT GATA } \\
\text { AACCTAGTTT } \\
\text { ACTCTAGCCT GGGCGACA } \\
\text { GAGCAAGACT } \\
\text { GACACACACA }\end{array}$} \\
\hline Angiomotin like 2 & AMOTL2 & Hs. 426312 & R67355 & 4.9 & -1.3 & 1.9 & -1.8 & 83.05 & -7553 & \\
\hline Annexin A1 & ANXA1 & Hs. 287558 & $\mathrm{H} 63077$ & 2.5 & 1.2 & 1.2 & -1.6 & 90.34 & -1049 & \\
\hline Apolipoprotein E & APOE & Hs. 110675 & AA478589 & 2.6 & 1.2 & 1.3 & -1.5 & 83.64 & -1059 & \\
\hline Connective tissue growth factor & CTGF & Hs. 410037 & AA598794 & 2.5 & -1.2 & 1.1 & -1.3 & 86.35 & -5982 & \\
\hline \multirow{2}{*}{$\begin{array}{l}\text { LATS, large tumor suppressor, } \\
\text { homolog } 2 \text { (Drosophila) } \\
\text { LYRIC/3D3 }\end{array}$} & LATS2 & Hs.78960 & N64139 & 2.7 & -1.0 & 1.1 & -1.3 & 92.84 & -2569 & \\
\hline & LYRIC & Hs.377155 & N92734 & 2.7 & 3.0 & 1.4 & 2.4 & 88.14 & -8550 & \\
\hline Muscleblind-like 2 (Drosophila) & MBNL2 & Hs.372571 & W16832 & 2.7 & 2.3 & 1.5 & 1.2 & 84.89 & -7220 & \\
\hline $\begin{array}{l}\text { Par- } 6 \text { partitioning defective } 6 \\
\text { homolog beta (C. elegans) }\end{array}$ & PARD6B & Hs.391828 & AA682861 & 2.3 & 1.2 & 1.1 & -1.1 & 83.35 & -9102 & \\
\hline $\begin{array}{l}\text { Par- } 6 \text { partitioning defective } 6 \\
\text { homolog beta (C. elegans) }\end{array}$ & PARD6B & Hs.391828 & AA054643 & 2.2 & 1.3 & 1.0 & -1.0 & 83.35 & -9102 & \\
\hline Prominin 1 & PROM1 & Hs.370052 & R40057 & 2.1 & 2.9 & 1.1 & 1.1 & 89.43 & -2682 & \\
\hline $\begin{array}{l}\text { Retinoblastoma binding } \\
\text { protein } 6\end{array}$ & RBBP6 & Hs. 188553 & $\mathrm{R} 88741$ & 2.2 & 1.6 & 1.2 & 1.7 & 87.58 & -2807 & \\
\hline SH3-domain binding protein 4 & SH3BP4 & Hs.17667 & AA156032 & 2.2 & 1.2 & 1.1 & 1.1 & 83.54 & -2148 & \\
\hline $\begin{array}{l}\text { SMAD specific E3 ubiquitin } \\
\text { protein ligase } 1\end{array}$ & SMURF1 & Hs.436249 & AA292087 & 2.1 & -1.0 & -1.1 & 1.1 & 92.88 & -1131 & \\
\hline $\begin{array}{l}\text { SMAD specific E3 ubiquitin } \\
\text { protein ligase } 2\end{array}$ & SMURF2 & Hs.387385 & AA479976 & 2.9 & -1.2 & 1.5 & -1.7 & 79.1 & -7104 & \\
\hline $\begin{array}{l}\text { Data not found } \\
\text { Data not found }\end{array}$ & & & $\begin{array}{l}\text { AA669710 } \\
\text { H84481 }\end{array}$ & $\begin{array}{l}2.3 \\
2.5\end{array}$ & $\begin{array}{l}1.6 \\
1.4\end{array}$ & $\begin{array}{l}1.3 \\
1.2\end{array}$ & $\begin{array}{r}1.5 \\
-1.4\end{array}$ & & & \\
\hline
\end{tabular}




\begin{tabular}{|c|c|c|c|c|c|c|c|c|c|c|}
\hline \multirow[b]{3}{*}{ Name } & \multirow[b]{3}{*}{ Symbol } & \multirow[b]{3}{*}{ UGCluster } & \multirow[b]{3}{*}{ Accession } & \multicolumn{4}{|c|}{ Expression (fold change) } & \multirow[b]{3}{*}{$\begin{array}{l}\text { Score p53 MH } \\
\text { algorithm }^{\mathrm{a}}\end{array}$} & \multirow[b]{3}{*}{$\begin{array}{l}\text { Putative } \\
\text { binding site }\end{array}$} & \multirow[b]{3}{*}{$\begin{array}{l}\text { Putative p53 binding } \\
\text { sequence }^{\mathrm{a}, \mathrm{b}}\end{array}$} \\
\hline & & & & \multicolumn{2}{|c|}{ p53+/+ } & \multicolumn{2}{|c|}{ p53-I- } & & & \\
\hline & & & & $8 \mathrm{~h}$ & $16 \mathrm{~h}$ & $8 \mathrm{~h}$ & $16 \mathrm{~h}$ & & & \\
\hline \multirow{3}{*}{$\begin{array}{l}\text { After } 16 \mathrm{~h} \\
\text { Baculoviral IAP repeat- } \\
\text { containing } 3 \\
\text { CGI-109 protein }\end{array}$} & & & & & & & & & & \multirow{4}{*}{$\begin{array}{l}\text { AAACTTGCTT AAA } \\
\text { ATACAAGCTG } \\
\text { GAACAAGTAT TTCTTAAT } \\
\text { TGCCTTGTTT }\end{array}$} \\
\hline & BIRC3 & Hs.127799 & AA002126 & 1.3 & -2.1 & 1.2 & -1.1 & 85.95 & -2071 & \\
\hline & CGI-109 & Hs.278391 & R53891 & 2.9 & 3.2 & 2.6 & 1.7 & 83.22 & -6213 & \\
\hline Chromosome 6 open reading & C6orf102 & Hs.20499 & H56052 & 1.0 & 2.1 & -1.2 & -1.3 & & & \\
\hline $\begin{array}{l}\text { Growth arrest and DNA- } \\
\text { damage-inducible protein }\end{array}$ & DDIT3 & Hs.392171 & AA015892 & 4.7 & 2.2 & 3.0 & -1.3 & 85.95 & -1847 & \multirow{2}{*}{$\begin{array}{l}\text { GGACTTGACC } \\
\text { CGCCTCCCCAGGT } \\
\text { CAACATGTCA } \\
\text { TCACATGACC } \\
\text { ACAGCTTAAGGGCT } \\
\text { GGGCATGTCC }\end{array}$} \\
\hline Muscleblind-like 2 (Drosophila) & MBNL2 & Hs.372571 & W16832 & 2.7 & 2.3 & 1.5 & 1.2 & 84.89 & -7220 & \\
\hline Prominin 1 & PROM1 & Hs.370052 & R40057 & 2.1 & 2.9 & 1.1 & 1.1 & 89.43 & -2682 & $\begin{array}{l}\text { TATCTAGCTC } \\
\text { ACAAAGTGACAG }\end{array}$ \\
\hline $\begin{array}{l}\text { Sel-1 suppressor of lin-12-like } \\
\text { (C. elegans) }\end{array}$ & SEL1L & Hs. 181300 & W90073 & 1.9 & 4.9 & 2.8 & 2.4 & 90.67 & -2195 & $\begin{array}{l}\text { CAGCATGTTT } \\
\text { ACAATCTGTTATA }\end{array}$ \\
\hline \multirow{5}{*}{$\begin{array}{l}\text { Small glutamine-rich } \\
\text { tetratricopeptide repeat (TPR)- } \\
\text { containing, beta } \\
\text { Transcribed locus } \\
\text { Tumor necrosis factor receptor } \\
\text { superfamily, member } 6 \\
\text { Data not found } \\
\text { Data not found } \\
\text { Data not found }\end{array}$} & SGTB & Hs. 268713 & R45567 & 1.2 & 2.7 & -1.0 & 1.1 & 98.6 & -9227 & $\begin{array}{l}\text { GGGCTAGCCT TG } \\
\text { TGACTTGCTT }\end{array}$ \\
\hline & \multirow{4}{*}{ TNFRSF6 } & \multirow{4}{*}{$\begin{array}{l}\text { Hs.386639 } \\
\text { Hs.82359 }\end{array}$} & R73909 & -1.0 & 2.0 & 1.1 & 1.0 & \multirow{4}{*}{90.92} & \multirow{4}{*}{653} & \multirow{4}{*}{$\begin{array}{l}\text { GGACAAGCCC } \\
\text { TGACAAGCCA }\end{array}$} \\
\hline & & & AA293571 & 1.1 & 2.4 & -1.2 & 1.0 & & & \\
\hline & & & $\begin{array}{l}\text { R43713 } \\
\text { R43721 }\end{array}$ & $\begin{array}{r}-2.0 \\
1.2\end{array}$ & $\begin{array}{r}-2.7 \\
3.0\end{array}$ & $\begin{array}{l}-1.3 \\
-1.2\end{array}$ & $\begin{array}{l}-1.3 \\
-1.1\end{array}$ & & & \\
\hline & & & AA169372 & -1.2 & $\begin{array}{l}3.0 \\
-2.4\end{array}$ & 1.1 & 1.1 & & & \\
\hline
\end{tabular}

${ }^{a}$ See reference Wang et $1 . .^{5}$ Decamer $\mathrm{p} 53$ binding motifs are indicated in bold. 

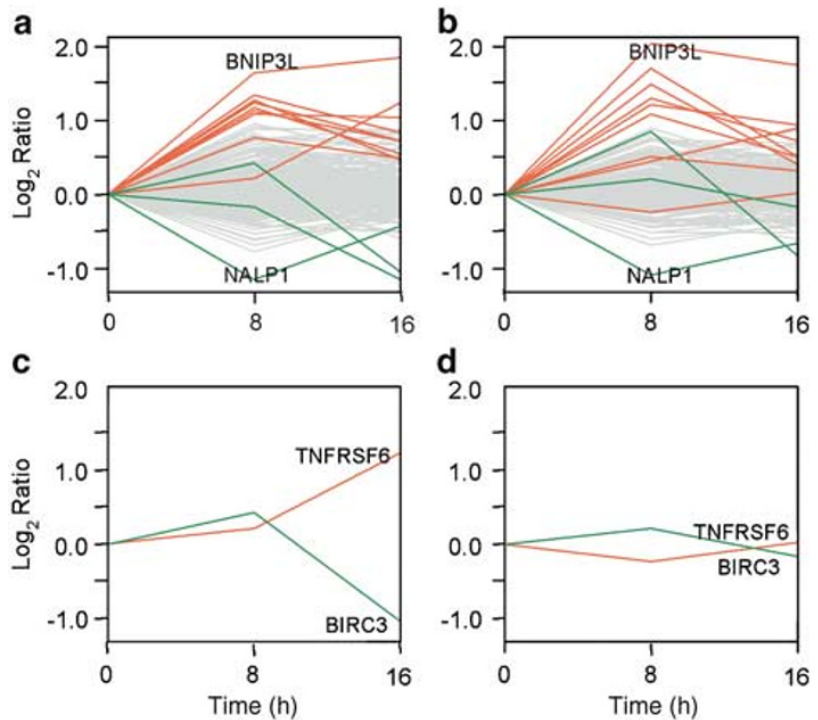

Figure 2 Gene expression relative to time point zero (before hypoxia treatment) of all 283 genes with Gene Ontology annotation apoptosis on the array is displayed for HCT116 wtp53 + I + cells in (a) and HCT116 p53-I - cells in (b). Genes which are significantly differentially expressed in response to hypoxia in at least one time point are colored in green if downregulated and red if upregulated. The genes are BNIP3L, BCLAF1, TXNL1, F2, STK17A, BNIP2, CYCS, TNFRSF10D, BIRC3, TNFRSF6, DUSP6 and NALP1, in decreasing order according to expression at time point $8 \mathrm{~h}$ in HCT116 wtp53 + I + cells. The two genes which are p53 dependently expressed are extracted in (c) and (d) to show their differing profiles in HCT116 wtp53 + / + and HCT116 p53-/ - cells, respectively

HIF1 promoter binding sites, for example, the main mediator of angiogenesis, VEGF, the proapoptotic gene BNIP3L and the endoplasmic reticulum oxidoreductin ERO1L, confirming the validity of our results. However, genes previously not associated with hypoxia were also identified, for example, the transcription factor JMJD1A, which is a negative regulator of cell growth signalling, and the ubiquitin-conjugating enzyme UBE2J1 (Supplementary Table 1 and Figure 1a-d).

Confirmation of microarray data by Northern blotting, reverse transcription-polymerase chain reaction and Western blotting. To confirm and extend the cDNA microarray data, we examined mRNA and/or protein expression of genes that showed p53-dependent expression in hypoxia-treated HCT116 cells according to the microarray analysis, as well as several known p53 target genes that were not represented on the array (Table 2). Northern blotting and quantitative reverse transcriptionpolymerase chain reaction (RT-PCR) confirmed significant p53-dependent induction of Fas/CD95 mRNA after 8 and $16 \mathrm{~h}$ of hypoxia treatment, demonstrating that Fas/CD95 induction is due to transcriptional transactivation (Figure 3a). We also confirmed p53-dependent induction of Fas/CD95 by Western blotting (Figure 3b), immunostaining (Figure $3 d$ ) and flow cytometry (Figure 3e, f). Likewise, we confirmed p53dependent induction of AMOTL2 mRNA at $8 \mathrm{~h}$ and DDIT3/ $\mathrm{CHOP}$ and SMURF1 protein at $16 \mathrm{~h}$ after hypoxia treatment (Figure 3a, b). Quantitative RT-PCR confirmed that SEL1L and SGTB were induced by hypoxia in a p53-dependent manner at 8 and/or $16 \mathrm{~h}$ (Table 2).
To determine if Fas/CD95 is induced by hypoxia in normal cells, we treated human diploid fibroblasts (HDFs) with hypoxia and examined Fas/CD95 expression by Western blotting. Figure $3 c$ shows that Fas/CD95 protein levels were markedly increased in these cells after 24 and $48 \mathrm{~h}$ of hypoxia. Hypoxia also induced Fas/CD95 protein expression in the wtp53-carrying LnCAP prostate carcinoma cells (Figure $3 \mathrm{~g}$ ). MCF-7 cells expressed low or undetectable levels of Fas/ CD95 both before and after hypoxia treatment, and U2OS cells expressed high levels of Fas/CD95 even at normoxia. Hypoxia did not induce Fas/CD95 in SW480 cells carrying mutant p53 (Figure 3g). Neither p21 nor PUMA were induced by hypoxia in any of the tested cells (Figure $3 \mathrm{~g}$ ).

To confirm that Fas/CD95 is a direct transcriptional target of p53 in response to hypoxia, we measured Fas/CD95 promoter activity in hypoxia-treated HCT116 cells using a luciferase reporter assay. This revealed a pronounced increase in luciferase activity upon hypoxia treatment (Figure 3h). We did not detect any increase in luciferase activity in hypoxia-treated HCT116 cells transfected with the same luciferase reporter construct containing the p21 promoter (Figure 3h). We conclude that Fas/CD95 is upregulated at the transcriptional level in response to hypoxia.

Our further analysis demonstrated that none of several known p53 target genes, including p21, GADD45, Noxa, Cathepsin D and PUMA, were induced by hypoxia in a p53-dependent manner at 8 or $16 \mathrm{~h}$ (Figure 4a, b; Table 2). Northern blotting and densitometric quantification revealed either no significant changes in expression levels in response to hypoxia or a similar induction in both p53 null- and wtp53expressing HCT116 cells. MDM2 mRNA was induced in both cell lines, but we observed a somewhat stronger induction in the wtp53-expressing cells at $16 \mathrm{~h}$ (Figure 4a; Table 2). This was even more pronounced in the Western blot analysis (Figure 4b; Table 2).

As a control, we treated the HCT116 cells with $\gamma$-irradiation and examined expression of the p53-target proteins p21, MDM2, PUMA and Fas/CD95 by Western blotting. All four proteins showed p53-dependent induction in response to $\gamma$-irradiation (Figure 4c).

In addition to transactivation of target genes, p53 can repress transcription of certain genes, including $\mathrm{Bcl}-2$ and hTERT. We therefore tested if hypoxia-induced p53 was able to affect expression of these two genes. As shown in Figure 4b, hypoxia caused a p53-dependent downregulation of both Bcl-2 and hTERT protein levels.

Fas/CD95 is required for p53-dependent apoptosis induced by hypoxia. Our finding that Fas/CD95 belongs to a limited set of genes that are induced by hypoxia in a p53dependent manner raised the possibility that Fas/CD95 and the death receptor pathway plays an important role in the p53-dependent apoptotic response to hypoxia. To test this, we treated HCT116 wtp53 + / + cells with an anti-Fas/CD95 antibody (APO-1) that blocks Fas/CD95 signalling and subsequently exposed the cells to hypoxia. We counted TUNEL-positive cells in both untreated and hypoxia-treated cultures in the presence or absence of the blocking antibody. We found that the cells treated with blocking anti-Fas/CD95 antibody were highly resistant to hypoxia-induced apoptosis 
a

HCT116-\% HCT116+/+

HYP (hrs) $00 \begin{array}{llllll} & 8 & 16 & 0 & 8 & 16\end{array}$

Fas/CD95
$\beta$-actin

$\begin{array}{llllll}1 & 1 & 0.73 & 1 & 2.18 & 3.09\end{array}$

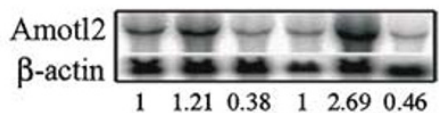

c

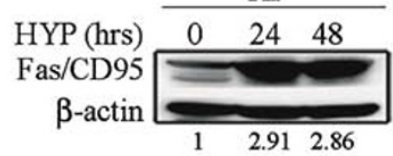

e

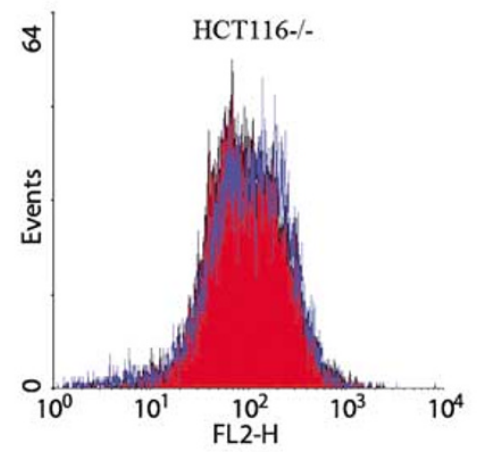

g

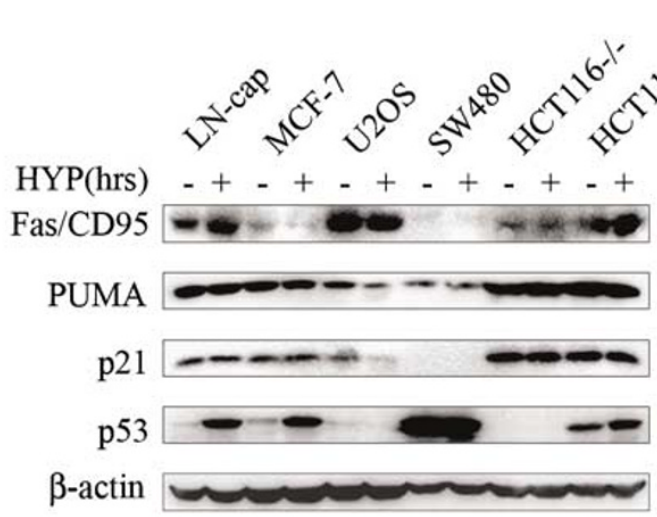

HCT116-/- HCT116+/+

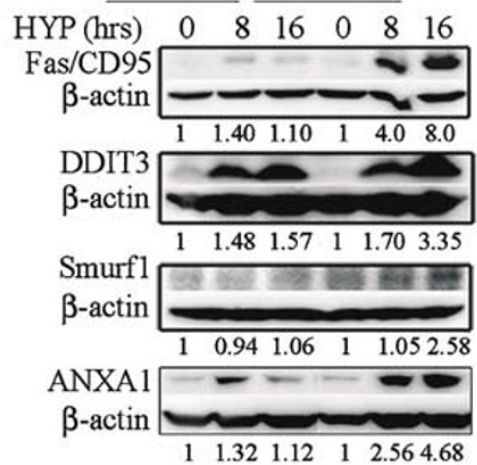

d

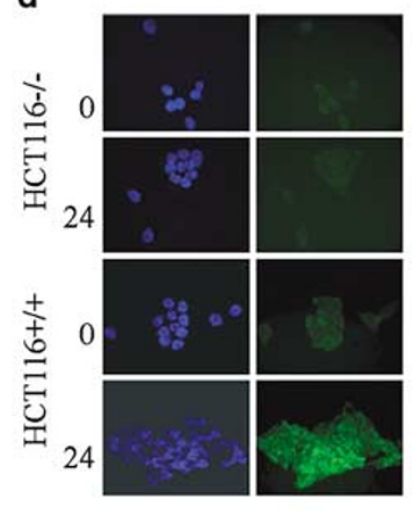

f

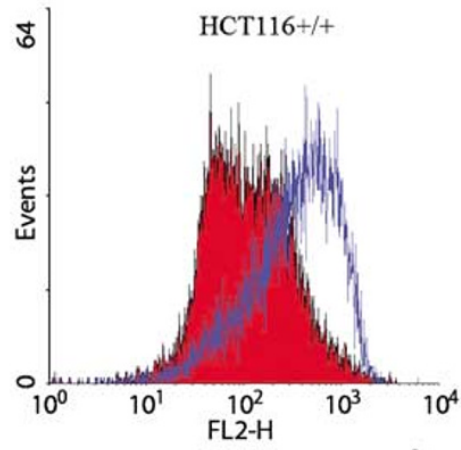

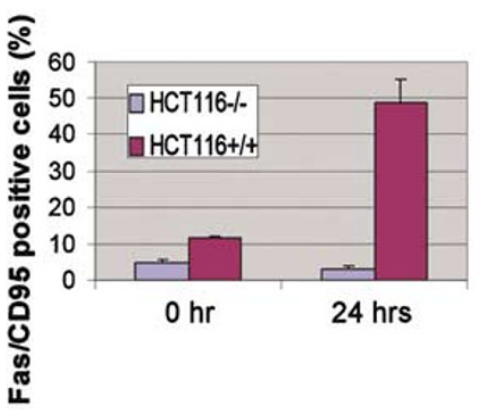

h

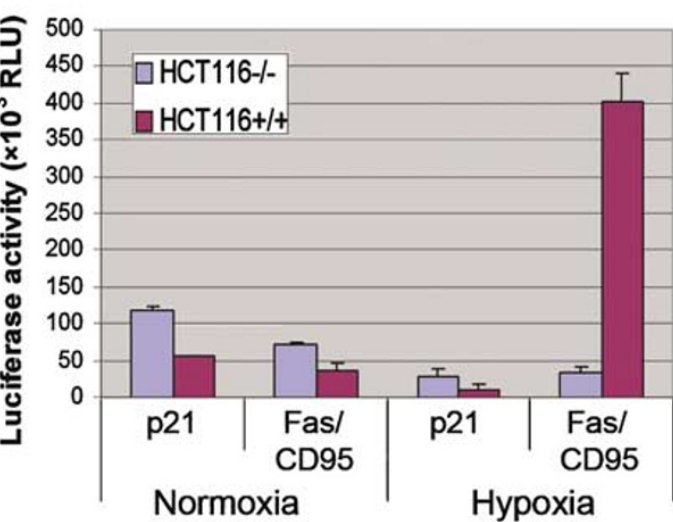

Figure 3 Confirmation of gene expression identified by microarray analysis. HCT116 cells (wtp53 $+/+$ and $-/-$ ) and HDFs were treated with hypoxia for the indicated time periods and analyzed by Northern or Western blotting. (a) Northern analysis of Fas/CD95 and AMOTL2 mRNA levels. (b) Western blot analysis of Fas/CD95, DDIT3, Smurf1 and ANXA1 expression. Densitometric quantification is shown below panels a and b. (c) Western blot analysis of Fas/CD95 expression in HDFs treated with hypoxia for the indicated time periods. (d) Immunofluorescence staining of Fas/CD95 in hypoxia-treated HCT116 cells. (e) Flow cytometry analysis of Fas/CD95 expression in untreated (solid red) and hypoxia-treated (blue line) HCT116 wtp53 $+/+$ and $-/-$ cells. (f) Quantification of Fas/CD95 expression according to flow cytometry. Error bars indicate standard error (S.E.). Mean values of \% Fas/CD95-poitive cells were $4.7 \pm 0.9$ and $3.2 \pm 0.3(P=0.238)$ for untreated and treated HCT116 wtp53-/- cells, respectively, and $11.8 \pm 0.6$ and $48.9 \pm 6.4(P=0.02864)$ for untreated and treated HCT1126 wtp53 $+1+$ cells, respectively. (g) Western blot analysis of Fas/CD95, PUMA p21 and p53 expression after $24 \mathrm{~h}$ of hypoxia in human tumor cell lines. (h) Luciferase reporter assays of p21 and Fas/CD95 promoter activity in response to hypoxia. Luciferase activity was measured in untreated and treated HCT116 cells transfected with p21 or Fas/CD95 reporter plasmids. Mean values for untreated and treated HCT116 wtp53 $+I+$ cells were $55.7 \pm 1.4$ and $11.0 \pm 6.7$, respectively $(P=0.01)$ for p21 and $37.2 \pm 8.5$ and $401.0 \pm 39.5$, respectively $(P=0.0059)$ for Fas/CD95. The data shown represent the average of triplicate experiments. Error bars indicate S.E.

(Figure 5a, b). We also treated HCT116 wtp53+/+ cells with a caspase 8 inhibitor (Z-IETD) to block the death receptor pathway before hypoxia treatment. Again, hypoxiainduced apoptosis was greatly reduced (Figure 5a, b). To confirm these results, we assessed apoptosis at $36 \mathrm{~h}$ of hypoxia by propidium iodide staining and flow cytometry. We observed a significant apoptosis in the HCT116 wtp53 + /+ cells (Figure $5 c, d$ ), which was blocked by either anti-Fas/ CD95 antibody or the caspase 8 inhibitor (Figure 5c, d). Similar results were obtained at $48 \mathrm{~h}$ (data not shown). Thus, 
a
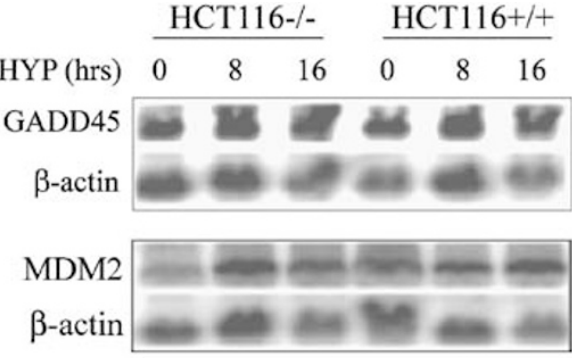

b
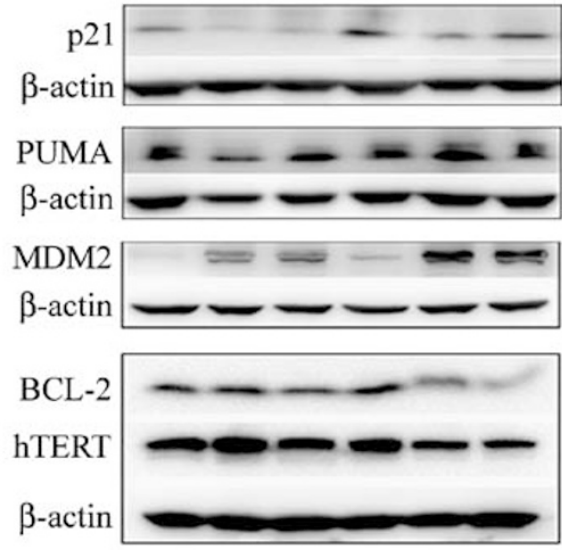

c
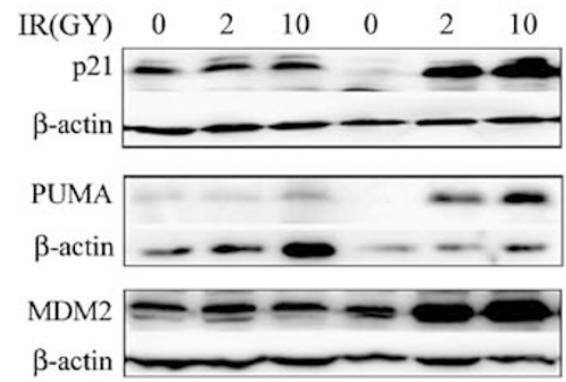

Fas/CD95

$\beta$-actin

Figure 4 Analysis of p53-dependent expression of known p53 target genes in response to hypoxia. HCT116 wtp53 + I + or HCT116 p53 null cells were exposed to hypoxia $(0.3 \%)$ and total RNA or protein was prepared and at the time points indicated. (a) Northern blot analysis of the expression of p53 target genes GADD45 and MDM2 in hypoxia-treated HCT116 cells. (b) Western blot analysis of p21, PUMA, MDM2, Bcl2 and hTERT protein levels in hypoxia-treated HCT116 cells. Densitometric quantification of the data in (a) and (b) is shown in Table 2. (c) Western blot analysis of p21, PUMA, MDM2 and Fas/CD95 protein levels in HCT116 cells treated with $\gamma$-irradiation (2 and $10 \mathrm{~Gy}$ )

we conclude that Fas/CD95 signalling is critical for the p53dependent apoptotic response to hypoxia in these cells.

\section{Discussion}

Hypoxia has been shown to trigger p53 accumulation and p53-dependent apoptosis in several systems. ${ }^{6,11,12}$ We asked whether hypoxia would trigger a p53-dependent gene expression pattern distinct from those induced by other stress agents, such as $\gamma$-irradiation and UV. Our analysis revealed significant p53-dependent induction or repression of only 27 genes among the 12454 different genes represented on the microarray. One known p53 target gene, Fas/CD95, showed significant p53-dependent induction. Further analysis by Northern blotting, RT-PCR and/or Western blotting confirmed that many p53 targets were not regulated in a p53-dependent manner in hypoxic cells. Some p53 target genes, such as p21 and KILLER/DR5, showed p53-independent upregulation in hypoxic cells. MDM2 also showed p53-independent regulation at both the mRNA and protein levels, but its induction in the wtp53-expressing cells was more pronounced than in the p53 null cells. Thus, although exposure to hypoxic conditions did trigger p53 accumulation and p53-dependent apoptosis, it induced a gene expression pattern that is considerably different from those induced by activation of exogenous wtp $53,{ }^{2,3}$ or DNA-damaging agents such as $\gamma$-irradiation.

Our finding that hypoxia does not induce p53-dependent expression of many p53 target genes is in agreement with a previous study showing that $\mathrm{p} 53$ activation by hypoxia mainly triggers p53-mediated transrepression via association of p53 with mSin $3 \mathrm{~A}$ and p53-mediated transrepression. ${ }^{8}$ However, it is evident from our results that hypoxia not only induces p53-dependent transrepression but also p53-dependent transactivation of a limited set of genes, many of which carry p53 binding motifs. Thus, one important conclusion from our study is that hypoxia-induced p53 is clearly capable of both transcriptional transactivation and transrepression. Notably, we observed p53-dependent induction of both MDM2 mRNA and protein in response to hypoxia, whereas others have reported that hypoxia induces MDM2 downregulation. 8,13

We demonstrate that Fas/CD95 is a critical p53 target in the hypoxia response, since Fas/CD95 is markedly upregulated by $\mathrm{p} 53$ in hypoxic cells and blocking Fas/CD95 signalling completely abrogated hypoxia-induced apoptosis. In addition, Fas/CD95 protein was also induced by hypoxia both in normal HDFs and in human prostate carcinoma cells. This highlights Fas/CD95 as a key effector of p53-induced apoptosis in response to hypoxia. Further work is needed to determine whether Fas/CD95 plays a similarly crucial role in the response to hypoxia in other cell types than those tested here. It remains unclear why Fas/CD95, but not p21, GADD45, PIG3 and other well-known p53 target genes, is induced in a p53-dependent manner in response to hypoxia. However, it is interesting to note that Fas/CD95 has a HIF1responsive element (HRE) located $1550 \mathrm{bp} 5^{\prime}$ of the transcription start site. The sequence of this HRE, TACGTGGG, matches the consensus sequence $B R C G T G B$, where $B=C$, $\mathrm{T}$ or $\mathrm{G}$, and $\mathrm{R}=\mathrm{A}$ or $\mathrm{G} .{ }^{14} \mathrm{MDM} 2$ also has an HRE (at position -2929), but this HRE (GACTTGGG) does not show a complete match with the consensus HRE. Thus, it is conceivable that HIF1 could act as a cofactor for p53mediated transactivation in hypoxic cells.

Our analysis revealed a number of previously unknown p53 target genes that showed increased or decreased p53dependent expression upon exposure to hypoxia. Several of these genes may have roles in processes such as growth control, maintenance of genome integrity, apoptosis and cancer. ANXA1 (ANNEXIN 1) is a member of the annexin family of calcium- and phospholipid-binding proteins and has proapoptotic effect in circulating neutrophils ${ }^{15}$ and rat thymo- 
Table 2 Verification of microarray data for (A) p53-dependent genes, (B) classical p53 target genes and (C) hypoxia-induced genes with real time PCR

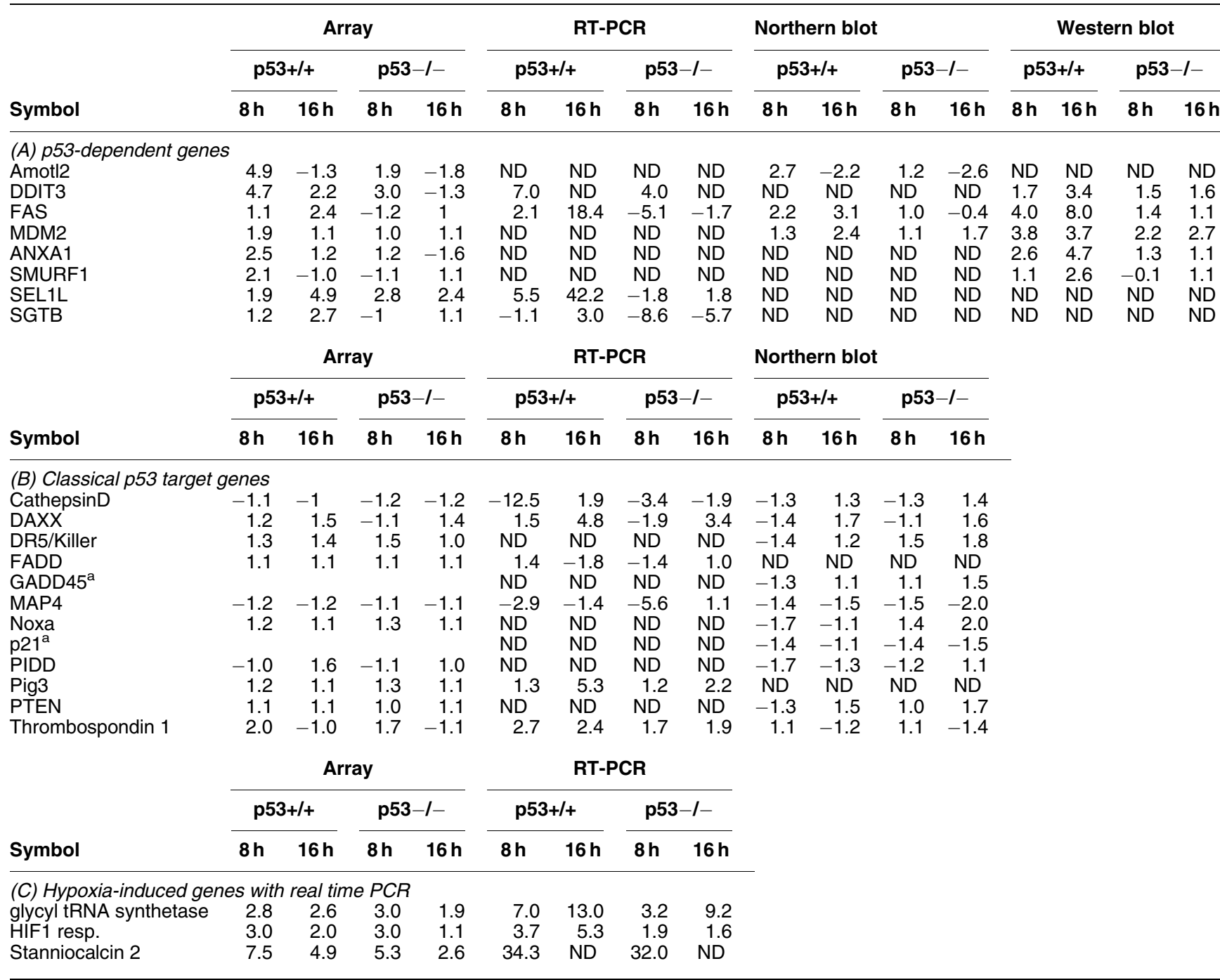

${ }^{a}$ Not on the array. ND $=$ not determined.

cytes. ${ }^{16}$ The observation that ANXA1 is expressed on the cell surface suggests that it may constitute an 'eat me' signal for removal of apoptotic cells. ${ }^{17}$ ANXA1 induces BAD dephosphorylation, allowing $B A D$ to associate with $B c l-X L$, which triggers the mitochondrial apoptosis pathway. ${ }^{15}$ ANXA1 has a p53 DNA binding motif located $1049 \mathrm{bp}$ from the transcription start site that matches the p53 consensus binding sites at 18 out of 20 positions (Table 1). Thus, p53-dependent upregulation of ANXA1 in hypoxic cells could contribute to the apoptotic response.

The DDIT3 gene, also known as GADD153 or CHOP, encodes an inhibitor of the transcription factor C/EBP and is induced by DNA damage. ${ }^{18}$ DDIT3 is frequently rearranged in myxoid liposarcomas owing to a characteristic $t(12 ; 16)(q 13 ; p 11)$ chromosomal translocation resulting in a fusion gene in which the RNA-binding domain of TLS is replaced by the DNAbinding domain and leucine zipper of DDIT3. ${ }^{19}$ Elevated DDIT3 expression was shown to sensitize cells to ER stress through downregulation of $\mathrm{Bcl}-2$ and increased production of reactive oxygen species. ${ }^{20} \mathrm{~A}$ recent study showed that DDIT3 is induced in hypoxia-treated rat embryonic heart-derived cells. Overexpression of DDIT3 sensitized these cells to hypoxia-induced apoptosis, whereas antisense GADD153 had the opposite effect. ${ }^{21}$ Like ANXA1, DDIT3 has at least one p53 binding site (Table 1).

The SEL1L gene shares sequence homology with the Caenorhabditis elegans sel-1 gene, an extragenic suppressor of the lin-12 hypomorphic mutant. ${ }^{22}$ SEL $1 \mathrm{~L}$ has been shown to inhibit Notch, and its yeast homolog IBD2 is involved in the Bub2p-dependent spindle checkpoint. $^{23}$ Human SEL1L is mainly expressed in the pancreas of healthy individuals but not in a significant fraction of pancreatic adenocarcinomas. ${ }^{24}$ Overexpression of SEL1L in pancreatic carcinoma cells caused decreased clonogenicity and anchorage-independent growth, and inhibited tumor xenograft growth in nude mice. The same study also indicated that SEL $1 \mathrm{~L}$ regulates expression of genes involved in cellular growth control, possibly through the TGF- $\beta$ signalling pathway. ${ }^{25}$ We identified at least 
a

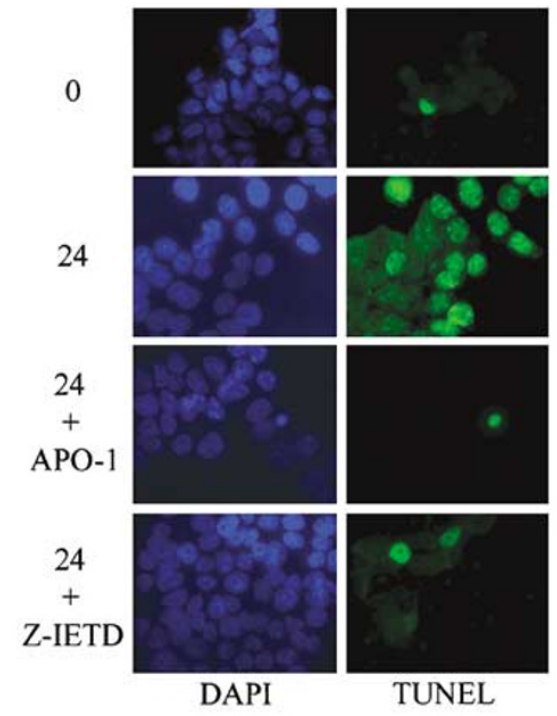

b

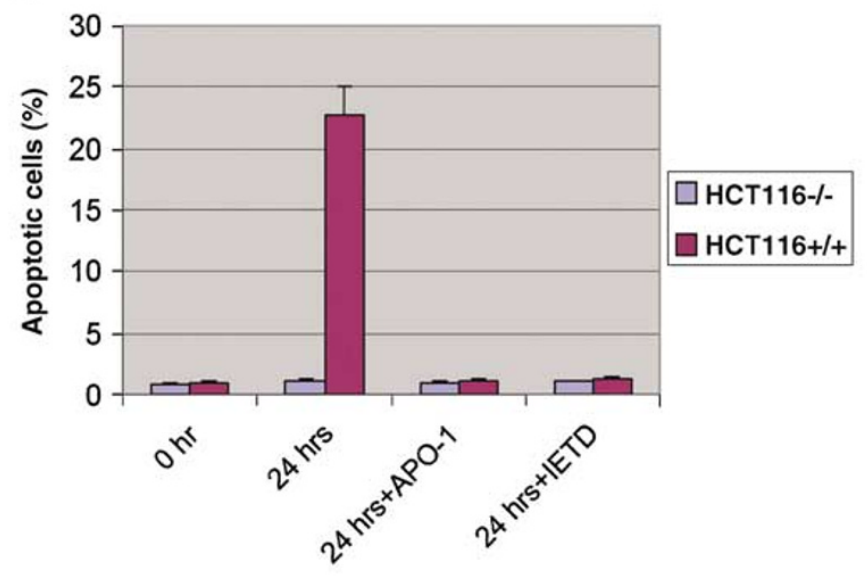

C

$0 \mathrm{hr}$

$36 \mathrm{hrs}$

$36 \mathrm{hrs}+\mathrm{APO}-1$

$36 \mathrm{hrs}+\mathrm{Z}-$ IETD
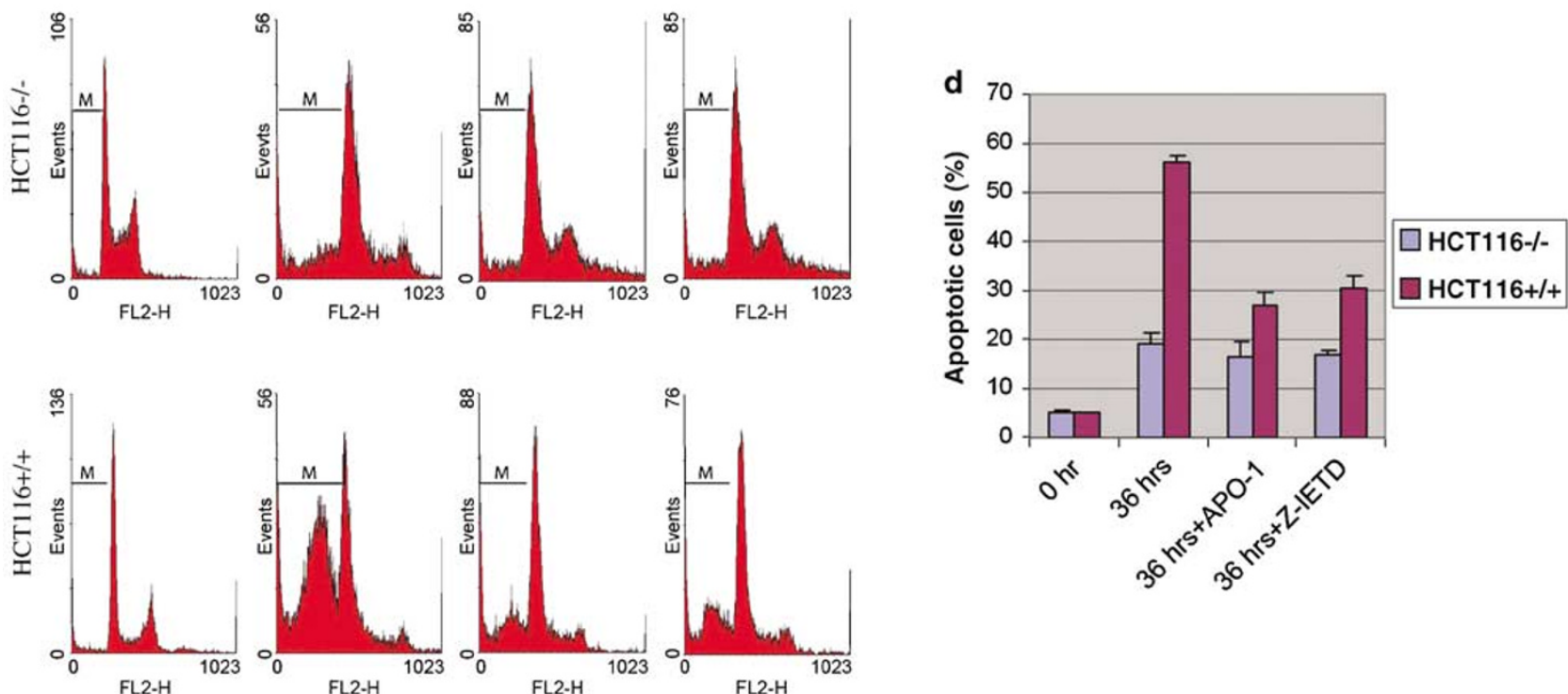

Figure 5 Hypoxia-induced apoptosis in HCT116 wtp53 + / + cells is dependent on Fas/CD95. (a) HCT116 wtp53 + / + cells were plated on glass coverslips, grown for $24 \mathrm{~h}$, treated by either anti-Fas/CD95-blocking antibody (APO-1) or caspase 8 inhibitor (Z-IETD) and exposed to hypoxia $\left(0.3 \% \mathrm{O}_{2}\right)$ for another $24 \mathrm{~h}$. Apoptosis was assessed by TUNEL staining. (b) Quantification of apoptosis by counting number of TUNEL-positive cells. The mean values of apoptosis for the untreated and hypoxia-treated HCT116 p53 null cells were $5 \pm 1$ and $7 \pm 1$, respectively $(P=0.058)$. For HCT116 wtp53 $+/+$ cells, the mean values for the untreated and hypoxia-treated cells were $6 \pm 0.6$ and $126 \pm 12.4$, respectively $(P=0.00005)$. The mean values for hypoxia-treated HCT116 wtp53 $+/+$ cells in the presence of $Z$-IETD or APO-1 were $7 \pm 1.0$ and $8 \pm 1.1$, respectively $(P=0.0041$ and $P=0.0034)$. The arithmetic mean is the average of values obtained by examination of four independent fields in each sample and for triplicate samples. (c) Apoptosis in hypoxia-treated HCT116 cells as assessed by propidium iodide staining and flow cytometry. Time points and blocking agents are indicated above each panel. Horizontal bars indicate apoptotic cells with sub-G1 DNA content. (d) Quantification of apoptosis by flow cytometry. Error bars represent S.E. Mean values were $4.4+0.5$ and $17.3 \pm 2.2(P=0.00339)$ for untreated and treated HCT116-/ - cells, respectively, and $19.2 \pm 2.2$ and $55.9 \pm 1.6(P=0.00001)$ for untreated and treated HCT116 $+/+$ cells, respectively. Mean values for hypoxia-treated HCT116 wtp53 + / + cells in the presence of either APO-1 or Z-IETD were $27.08 \pm 2.44$ and $30.4 \pm 2.6$, respectively $(P=0.0006$ and $P=0.00118)$

one potential p53 binding site at position -2195 in the SEL1L gene (Table 1).

LATS2, the human homolog of the Drosophila large tumor suppressor gene, encodes a putative nuclear Ser/Thr kinase expressed in several human tissues. Homozygous inactivation of LATS2 in mice resulted in embryonic lethality and LATS2 null mouse embryo fibroblasts showed increased growth potential, cytokinesis defects and aneuploidy. ${ }^{26}$
Interestingly, LATS2 was shown to induce apoptosis through downregulation of the antiapoptotic $\mathrm{Bcl}-2$ and $\mathrm{Bcl}-\mathrm{XL}$ proteins. $^{27}$

Other genes identified in our microarray analysis may also play roles in p53-dependent hypoxia-induced apoptosis. AMOTL2 was identified as a novel member of the angiomotin family. ${ }^{28}$ Angiomotin itself may promote angiogenesis by increasing cell motility. ${ }^{29}$ The exact function of AMOTL2 and 
its involvement in regulation of cell motility, growth and survival, if any, remains to be established. ASXL1 encodes a polycomb group protein belonging to the CXXC gene family that has been implicated in tumor development through transcriptional regulation of target genes. ${ }^{30}$ The product of the RBBP6 gene binds the retinoblastoma protein, a central regulator of cell cycle progression and cell survival. ${ }^{31}$ SMURF1 and SMURF2 both encode E3 ubiqutin ligases regulating Smad proteins in the TGF- $\beta$ signalling pathway that control cell proliferation, differentiation, migration and survival. ${ }^{32}$ p53-dependent activation of SMURF1 and/or SMURF2 expression in response to hypoxia could lead to inhibition of this pathway and thus affect cell growth and survival.

In addition to these novel upregulated p53 target genes, we identified HIAP1/BIRC3 as a p53 repressed gene in hypoxiatreated cells. The HIAP1/BIRC3 protein was shown to inhibit apoptosis by interfering with caspase activation at the apoptosome; its displacement resulted in caspase 3 activation and release from the complex. ${ }^{33}$ HIAP1/BIRC3 inhibits caspase 8-dependent TRAIL/Apo2L-induced apoptosis, linking this protein to the death receptor apoptosis pathway. ${ }^{34}$ Thus, downregulation of HIAP1/BIRC3 may contribute to p53induced apoptosis in response to hypoxia.

In conclusion, we have shown that hypoxia triggers a p53dependent gene expression pattern that is distinct from those induced by other stress agents and involves both transcritional transactivation and transrepression of downstream targets. This demonstrates that the ability of $p 53$ to regulate the gene expression is to a large extent dependent on the type of stress agent that triggers the p53 response. Different stress agents may presumably induce differential p53-dependent gene expression patterns via activation of specific cofactors that are required for transcriptional regulation of p53 target genes. HIF1 is obviously a possible cofactor in the case of hypoxia. Furthermore, post-translational modifications of p53, for example, phosphorylation, acetylation and sumoylation, could affect the ability of p53 to transactivate or repress target genes by modulating the interaction of p53 with co-activators or co-repressors such as p300 and mSin3A. ${ }^{8,35}$ Importantly, our analysis has led to the identification of a number of new p53 target genes that may have essential roles in the control of cell growth, cell survival and genomic integrity. Further studies of these genes should provide important information about the p53 response to cellular stress and how p53 antagonizes tumor growth.

\footnotetext{
Materials and Methods

Cell culture and hypoxia treatment. Cells were grown in Iscove's modified Dulbecco's medium with 10\% fetal bovine serum (FBS) (Invitrogen, UK), $2 \mathrm{mM}$ L-glutamine (Sigma-Aldrich, Germany) and $50 \mu \mathrm{g} / \mathrm{ml}$ gentamicin (SigmaAldrich, Germany) at $37^{\circ} \mathrm{C}$ in $5 \% \mathrm{CO}_{2}$. $\mathrm{HCT} 116$ human colon carcinoma cells carrying wtp53 (HCT116 wtp53 + / ) and a p53 null subline (HCT116 p53-/-) were provided by Bert Vogelstein, Johns Hopkins University. Normal HDFs were provided by Anders Zetterberg, Karolinska Institute, and cultured in Dulbecco's modified Eagle's medium with $10 \% \mathrm{FBS}, 50 \mu \mathrm{g} / \mathrm{ml}$ gentamicin and $2 \mathrm{mM} \mathrm{L}$ glutamine. Experiments were carried out with HDFs at passage 12. An oxygen concentration of $0.3 \%$ was obtained by flushing a sealed box containing the cells with premixed gas composed of $95 \%$ nitrogen $\left(\mathrm{N}_{2}\right)$ and $5 \% \mathrm{CO}_{2}$ (AGA AB, Sweden). To obtain an oxygen concentration of $0.05 \%$, the cells were flushed with the premixed gas continuously throughout the experiment.
}

RNA extraction. Total cellular RNA from HCT116 cells was prepared using the TRIzol reagent (Invitrogen, UK) from frozen cell pellets according to the manufacturer's protocol. RNA concentration was determined in a spectrophotometer and quality of total RNA was verified by electrophoresis on a $1 \%$ agarose gel.

Microarray analysis. The microarrays consisted of 20352 cDNA fragments from the sequence-verified human clone collection 97001.V, plates 1-212 (Research Genetics, AL, USA), corresponding to 12454 unique Unigene IDs. The CDNAs were spotted onto Ultra GAPS slides (Corning, NY, USA) with a QArray (Genetix, UK) instrument (for more information, see A-MEXP-254 at Array Express, www.ebi.ac.uk/arrayexpress). Target cDNA was generated by oligo dT-mediated RT of $15 \mu \mathrm{g}$ of total RNA, indirectly labelled using amino-allyl-modified nucleotides, and hybridized as described (www.ktharray.se). RNA was extracted from HCT116 wtp53 $+I+$ and p53 null cells at time points 0,8 and $16 \mathrm{~h}$ of hypoxia treatment $(0.05 \%)$. The microarray hybridizations were performed in triplicates including one dye-swap, 0-8, 8-16, and 16-0 h. The arrays were scanned at 532 and $635 \mathrm{~nm}$ with 10- $\mu \mathrm{m}$ resolution using a G2565BA DNA microarray scanner (Agilent Technologies, CA, USA). Image analysis was performed in GenePixPro 5.0 software (Axon instruments, CA, USA), where spots were removed from further analysis if less than $70 \%$ of foreground pixels were below background intensity plus two S.D. in both channels, or if the signal to noise ratio was below three in both channels, or if the difference between ratio of medians and regression ratio exceeded $20 \%$ in one of the channels. After removal of bad quality spots, the remaining intensities were print tip lowess normalized in the $R$ environment for statistical computing (R Development Core Team, http://www.R-project.org) with the com.braju.sma package (Bengtsson $\mathrm{H}$, http://www.maths.lth.se/publications). An empirical bayes method (B-test) implemented in the Limma package ${ }^{36}$ was used for ranking differentially expressed genes. For significant hypoxia-induced differential expression, the genes were to have $B>0,|M|>1$ and $P<0.01$ comparing before and after treatment at each time point. In addition to significant hypoxia response, the genes were required to fulfill the same criteria for the comparisons between cell lines for significant hypoxia-induced p53 dependence. All microarray data are available at Array Express (www.ebi.ac.uk/arrayexpress).

Northern blot analysis and quantitative RT-PCR. RNA samples $(30 \mu \mathrm{g})$ were fractionated on $1 \%$ agarose gels in $2.2 \mathrm{M}$ formaldehyde, transferred onto a nylon membrane, and hybridized with ${ }^{32} \mathrm{P}$-labelled probes. Signals were recorded on an FLA-3000 phosphoimager (Fujifilm, Sweden). Densitometry was performed using Image Gauge version 3.12 analysis software (Fujifilm, Sweden). Quantitative RT-PCR was carried out with the iCycler iQ system with Supermix (Bio-Rad, CA, USA) according to the kit's protocol, or with Taqman probes with TaqMan ${ }^{\circledR}$ Universal PCR Master Mix (Applied Biosystems, CA, USA), according to the manufacturer's recommendations. Primer sequences are shown in Supplementary Table 2.

Antibodies, Western blotting, immunostaining and TUNEL. Antip53 antibody DO-1 and anti-p21 antibody 6B6 were from BD Bioscience (San Diego, CA, USA), anti-Ser-15-phosphorylated p53 antibody $16 \mathrm{G} 8$ was from Cell Signaling Technology (Beverly, MA, USA), anti-MDM2 antibody N-20 and antiSmurf1 antibody were from Santa Cruz (San Diego, CA, USA), anti-Puma antibody ab9643 was from Abcam (Cambridge, UK), anti-Fas/CD95 antibody B10 was from Santa Cruz (San Diego, CA, USA), anti-Fas/CD95-blocking antibody APO-1 was from Nordic BioSite (Stockholm Sweden), mouse anti-hTERT antibody NCL-hTERT was from Novocastra (Newcastle, UK) and anti- $\beta$-actin antibody was from Sigma (St Louis, MO, USA). HCT116 cells were seeded on glass coverslips $\left(10^{5}\right.$ cells/well), grown for $24 \mathrm{~h}$ and treated by hypoxia $\left(0.3\right.$ or $\left.0.05 \% \mathrm{O}_{2}\right)$. Western blotting and immunofluorescence staining were carried out as described by Lindstrom and Wiman. ${ }^{37}$ Staining was viewed using an Axioplan II (3D) microscope equipped with an AxioCam CCD camera (Carl Zeiss, Oberkochen, Germany). TUNEL was performed as described by Rahman et al. ${ }^{38}$ TUNEL-positive cells were counted in a defined field in four different areas of each slide to obtain a mean number. The experiments were performed with triplicate samples.

Luciferase reporter assay. HCT116 cells were seeded in 24-well plates $\left(6 \times 10^{4}\right.$ cells/well) $24 \mathrm{~h}$ before transfection and transfected with $100 \mathrm{ng}$ of Fas ${ }^{39}$ or p21 $1^{40}$ luciferase reporter plasmid using Lipofectamine2000 (Invitrogen Corp., CA, USA). At $24 \mathrm{~h}$ after transfection, the cells were exposed to hypoxia $(0.3 \%)$ or maintained at normoxia for another $24 \mathrm{~h}$. Luciferase activity was assessed with the 
Luciferase Reporter Assay system (Promega, WI, USA) and a luminometer (Berthold Technologies, TN, USA) according to the manufacturer's instructions.

Flow cytometry. Samples were analyzed on a fluorescence-activated cell sorter (FACSCalibur flow cytometer, Becton Dickinson, San Jose, CA, USA). For propidium iodide staining and analysis of DNA fragmentation, $\mathrm{HCT116}$ cells were plated onto six-well plates at a density of $4 \times 10^{5}$ cells/well 1 day before treatment. Cells were exposed to hypoxia $\left(0.3 \% \mathrm{O}_{2}\right)$ or maintained at normoxia for another 36 or $48 \mathrm{~h}$. Cells were then fixed and stained with propidium iodide and analyzed on the flow cytometer according to a standard procedure. For Fas/CD95 expression, HCT 116 cells were treated as above for $24 \mathrm{~h}$, rinsed with PBS twice and incubated for $5 \mathrm{~min}$ in PBS containing $1 \mathrm{mM}$ Versen in order to detach the cells. The cell suspension was then rinsed twice in TBS and incubated for $30 \mathrm{~min}$ on ice with the phycoerythrin-conjugated anti-human Fas/CD95 monoclonal antibody. Finally, cells were rinsed twice with TBS, resuspended in $500 \mu$ IBS and analyzed by FACSCalibur. Data were analyzed by Microcal Origin statistical software. Flow cytometry data were analyzed by WinMDI 2.8 software (Scripps Research Institute, CA, USA).

Acknowledgements. We thank Thierry Soussi and Vladimir Bykov for valuable advice and reagents, Bert Vogelstein and Anders Zetterberg for providing cells, Katarina Gradin for technical help with hypoxia treatment and Annelie Waldén for microarray production. This work was supported by the Swedish Cancer Society, Karolinska Institute, Ingabritt och Arne Lundberg Foundation, the Swedish Society of Medicine, the Wallenberg Consortium North, the Nilsson-Ehle Foundation (Lund), and the Swedish Research Council.

1. Vousden KH, Lu X. Live or let die: the cell's response to p53. Nat Rev Cancer 2002; 2 594-604.

2. Zhao R, Gish K, Murphy M, Yin Y, Notterman D, Hoffman WH et al. Analysis of p53 regulated gene expression patterns using oligonucleotide arrays. Genes Dev 2000; 14: 981-993.

3. Kannan K, Amariglio N, Rechavi G, Jakob-Hirsch J, Kela I, Kaminski N et al. DNA microarrays identification of primary and secondary target genes regulated by $\mathrm{p} 53$. Oncogene 2001; 20: 2225-2234.

4. Hoh J, Jin S, Parrado T, Edington J, Levine AJ, Ott J. The p53MH algorithm and its application in detecting p53-responsive genes. Proc Natl Acad Sci USA 2002; 99: 84678472.

5. Wang L, Wu Q, Qiu P, Mirza A, McGuirk M, Kirschmeier P et al. Analyses of p53 target genes in the human genome by bioinformatic and microarray approaches. $J$ Biol Chem 2001; 276: 43604-43610.

6. Graeber TG, Peterson JF, Tsai M, Monica K, Fornace Jr AJ, Giaccia AJ. Hypoxia induces accumulation of p53 protein, but activation of a G1-phase checkpoint by low-oxygen conditions is independent of p53 status. Mol Cell Biol 1994; 14: 6264-6277.

7. Graeber TG, Osmanian C, Jacks T, Housman DE, Koch CJ, Lowe SW et al. Hypoxiamediated selection of cells with diminished apoptotic potential in solid tumours. Nature 1996; 379: 88-91.

8. Koumenis $\mathrm{C}$, Alarcon R, Hammond E, Sutphin P, Hoffman W, Murphy M et al. Regulation of p53 by hypoxia: dissociation of transcriptional repression and apoptosis from p53dependent transactivation. Mol Cell Biol 2001; 21: 1297-1310.

9. Hammond EM, Dorie MJ, Giaccia AJ. ATR/ATM targets are phosphorylated by ATR in response to hypoxia and ATM in response to reoxygenation. $J$ Biol Chem 2003; 278 12207-12213.

10. Bardos JI, Ashcroft M. Negative and positive regulation of HIF-1: a complex network. Biochim Biophys Acta 2005; 1755: 107-120.

11. Zhu Y, Mao XO, Sun $Y$, Xia Z, Greenberg DA. p38 Mitogen-activated protein kinase mediates hypoxic regulation of Mdm2 and p53 in neurons. J Biol Chem 2002; 277: 2290922914.

12. Stempien-Otero A, Karsan A, Cornejo CJ, Xiang H, Eunson T, Morrison RS et al. Mechanisms of hypoxia-induced endothelial cell death. Role of p53 in apoptosis. J Bio Chem 1999; 274: 8039-8045.

13. Alarcon R, Koumenis C, Geyer RK, Maki CG, Giaccia AJ. Hypoxia induces p53 accumulation through MDM2 down-regulation and inhibition of E6-mediated degradation. Cancer Res 1999; 59: 6046-6051.
14. Wenger RH, Stiehl DP, Camenisch $\mathrm{G}$. Integration of oxygen signaling at the consensus HRE. Sci STKE 2005; 2005: re12.

15. Solito E, Kamal A, Russo-Marie F, Buckingham JC, Marullo S, Perretti M. A novel calciumdependent proapoptotic effect of annexin 1 on human neutrophils. FASEB J 2003; 17: $1544-1546$

16. Sakamoto T, Repasky WT, Uchida K, Hirata A, Hirata F. Modulation of cell death pathways to apoptosis and necrosis of $\mathrm{H}_{2} \mathrm{O}_{2}$-treated rat thymocytes by lipocortin I. Biochem Biophys Res Commun 1996; 220: 643-647.

17. Arur S, Uche UE, Rezaul K, Fong M, Scranton V, Cowan AE et al. Annexin I is an endogenous ligand that mediates apoptotic cell engulfment. Dev Cell 2003; 4: 587-598.

18. Luethy JD, Holbrook NJ. Activation of the gadd 153 promoter by genotoxic agents: a rapid and specific response to DNA damage. Cancer Res 1992; 52: 5-10.

19. Crozat A, Aman P, Mandahl N, Ron D. Fusion of CHOP to a novel RNA-binding protein in human myxoid liposarcoma. Nature 1993; 363: 640-644.

20. McCullough KD, Martindale JL, Klotz LO, Aw TY, Holbrook NJ. Gadd153 sensitizes cells to endoplasmic reticulum stress by down-regulating $\mathrm{Bcl} 2$ and perturbing the cellular redox state. Mol Cell Biol 2001; 21: 1249-1259.

21. Han XJ, Chae JK, Lee MJ, You KR, Lee BH, Kim DG. Involvement of GADD153 and cardiac ankyrin repeat protein in hypoxia-induced apoptosis of $\mathrm{H} 9 \mathrm{c} 2$ cells. J Biol Chem 2005; 280: 23122-23129.

22. Grant B, Greenwald I. Structure, function, and expression of SEL-1, a negative regulator of LIN-12 and GLP-1 in C. elegans. Development 1997; 124: 637-644.

23. Hwang HS, Song K. IBD2 encodes a novel component of the Bub2p-dependent spindle checkpoint in the budding yeast Saccharomyces cerevisiae. Genetics 2002; 161: 595-609.

24. Biunno I, Appierto V, Cattaneo M, Leone BE, Balzano G, Socci C et al. Isolation of a pancreas-specific gene located on human chromosome 14q31: expression analysis in human pancreatic ductal carcinomas. Genomics 1997; 46: 284-286.

25. Cattaneo M, Orlandini S, Beghelli S, Moore PS, Sorio C, Bonora A et al. SEL1L expression in pancreatic adenocarcinoma parallels SMAD4 expression and delays tumor growth in vitro and in vivo. Oncogene 2003; 22: 6359-6368.

26. McPherson JP, Tamblyn L, Elia A, Migon E, Shehabeldin A, Matysiak-Zablocki E et al. Lats2/Kpm is required for embryonic development, proliferation control and genomic integrity. EMBO J 2004; 23: 3677-3688.

27. Ke H, Pei J, Ni Z, Xia H, Qi H, Woods T et al. Putative tumor suppressor Lats2 induces apoptosis through downregulation of Bcl-2 and Bcl-x(L). Exp Cell Res 2004; 298: 329-338.

28. Bratt A, Wilson WJ, Troyanovsky B, Aase K, Kessler R, Van Meir EG et al. Angiomotin belongs to a novel protein family with conserved coiled-coil and PDZ binding domains. Gene 2002; 298: 69-77.

29. Troyanovsky B, Levchenko T, Mansson G, Matvijenko O, Holmgren L. Angiomotin: an angiostatin binding protein that regulates endothelial cell migration and tube formation. J Cell Biol 2001; 152: 1247-1254.

30. Fisher CL, Berger J, Randazzo F, Brock HW. A human homolog of Additional sex combs, ADDITIONAL SEX COMBS-LIKE 1, maps to chromosome 20q11. Gene 2003; 306: 115126.

31. Sakai $Y$, Saijo M, Coelho K, Kishino T, Niikawa N, Taya $Y$. cDNA sequence and chromosomal localization of a novel human protein, RBQ-1 (RBBP6), that binds to the retinoblastoma gene product. Genomics 1995; 30: 98-101.

32. Moustakas A, Heldin $\mathrm{CH}$. From mono- to oligo-Smads: the heart of the matter in TGF-beta signal transduction. Genes Dev 2002; 16: 1867-1871.

33. Semenkova L, Dudich E, Dudich I, Tokhtamisheva N, Tatulov E, Okruzhnov Y et al. Alphafetoprotein positively regulates cytochrome $c$-mediated caspase activation and apoptosome complex formation. Eur J Biochem 2003; 270: 4388-4399.

34. Mitsiades N, Mitsiades CS, Poulaki V, Anderson KC, Treon SP. Concepts in the use of TRAIL/Apo2L: an emerging biotherapy for myeloma and other neoplasias. Expert Opin Investig Drugs 2001; 10: 1521-1530.

35. Appella E, Anderson CW. Post-translational modifications and activation of p53 by genotoxic stresses. Eur J Biochem 2001; 268: 2764-2772.

36. Smyth $\mathrm{G}$. Linear models and empirical bayes methods for assessing differential expression in microarray experiments. Statistical Applications in Genetics and Molecular Biology 2004; vol. 3 (Article 3)

37. Lindstrom MS, Wiman KG. Myc and E2F1 induce p53 through p14ARF-independent mechanisms in human fibroblasts. Oncogene 2003; 22: 4993-5005.

38. Rahman R, Latonen L, Wiman KG. hTERT antagonizes p53-induced apoptosis independently of telomerase activity. Oncogene 2005; 24: 1320-1327.

39. Muller M, Wilder S, Bannasch D, Israeli D, Lehlbach K, Li-Weber M et al. p53 activates the CD95 (APO-1/Fas) gene in response to DNA damage by anticancer drugs. J Exp Med 1998; 188: 2033-2045.

40. el-Deiry WS, Tokino T, Velculescu VE, Levy DB, Parsons R, Trent JM et al. WAF1, a potential mediator of p53 tumor suppression. Cell 1993; 75: 817-825.

Supplementary Information accompanies the paper on Cell Death and Differentiation website (http://www.nature.com/cdd) 